УдК 633.111.1"324":631.527:631.524

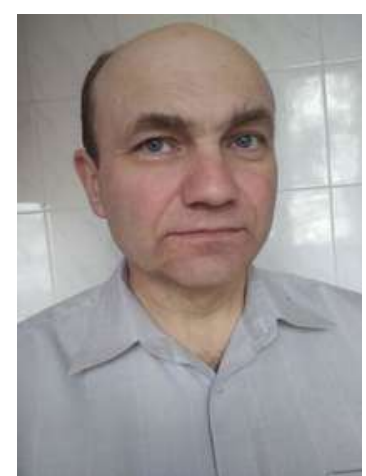

\title{
В.3. Іодковський,
}

науковий співробітник лабораторії

селекції та фізіології пшениці

Інститут рослинництва імені В.Я. Юр'єва НАAН

м. Харків, Україна.

E-mail: iodkovskijvl@gmail.com

DOI: $10.31395 / 2310-0478-2021-1-39-47$

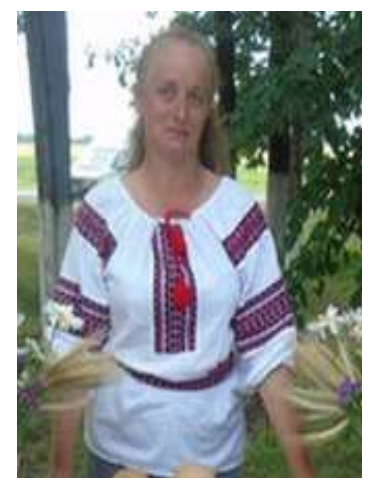

\section{3.В. Усова,}

кандидат сільськогосподарських наук, старший науковий співробітник, провідний науковий співробітник лабораторії селекції та фізіології пшениці

Інститут рослинництва імені В.Я. Юр'єва НАAН

м. Харків, Україна.

E-mail: ppiww2017@gmail.com

К.Ю. Суворова, кандидат біологічних наук, старший науковий співробітник лабораторії селекції та фізіології пшениці Інститут рослинництва імені В.Я. Юр'єва НААН м. Харків, Україна. E-mail: katasuvorova630@gmail.com

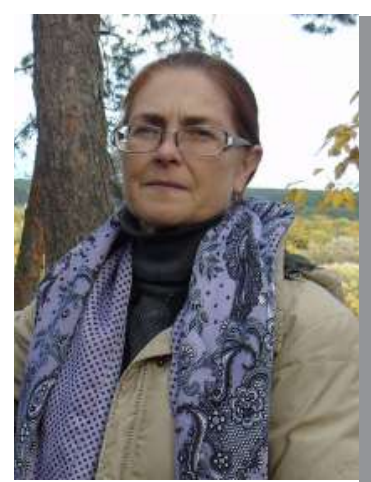

доктор сільськогосподарських наук, старший науковий співробітник, завідувач лабораторії селекції та фізіології пшениці Інститут рослинництва імені В.Я. Юр'єва НАAН м. Харків, Україна. E-mail: oleleo@meta.ua

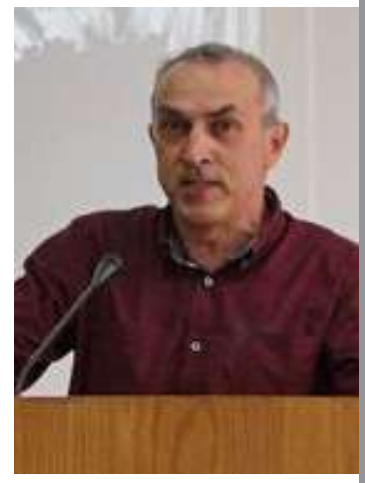

0.0. Скрипник, молодший науковий співробітник лабораторії селекції та фізіології пшениці Інститут рослинництва імені В.Я. Юр'єва НАAН м. Харків, Україна. E-mail: anastasiamishenuk2004@gmail.com

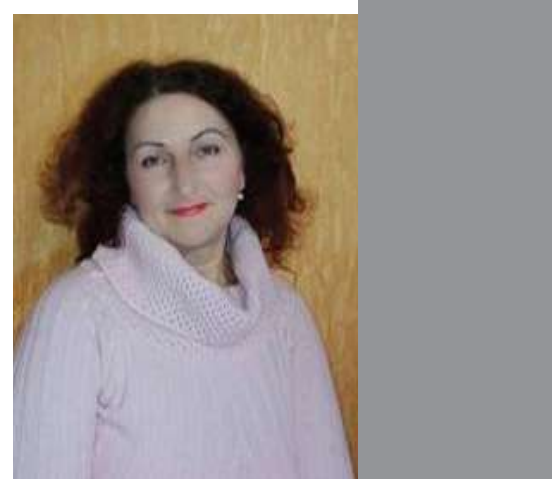

\section{ОЦІНКА СОРТІВ ПШЕНИЦІ ОЗИМОÏ ЗА ЕКОЛОГІЧНОЮ ПЛАСТИЧНІСТЮ ТА СТАБІЛЬНІСТЮ ОСНОВНИХ ГОСПОДАРСЬКИХ ОЗНАК}

У статті наведено результати вивчення сортів і ліній пшениці м'якої озимої селекції Інституту рослинництва ім. В.Я. Юр'єва НААН за пластичністю та стабільністю показників врожайності, вмісту білка в зерні, сили борошна. Встановлено, що всі сорти за цими показниками відносяться до пластичних. Методом кластерного аналізу проведено групування сортів за рівнем прояву цих ознак. За урожайністю високий рівень пластичності, близький до стандартів Подолянка і Смуглянка, відмічено у сортів: Досконала, Альянс, Здобна, Метелиця харківська, Гайок. Низькопластичними виявилися сорти: Запашна, Еритроспермум 832-14, Мальованка, Краса ланів, які забезпечували стабільно високий урожай на рівні стандарту Бунчук. Аналіз вмісту білка в досліджуваних зразках пшениці озимої за результатами визначення коефіцієнту регресії та розподілу за кластерним аналізом показав, що пластичними сортами з найвищим серед вивчених зразків вмістом білка в зерні $\epsilon$ сорти: Проня, Гармоніка, Принада, Привітна, Приваблива, Дорідна, стандарт Бунчук. Сорти цієї групи належать до сортів універсального типу використовування, які незалежно від умов вирощування формують зерно 1-2 класу. Високі показники сили борошна від 242 од. а. до 281 од. а. притаманні сортам групи стандарту Смуглянка: Коровайна, Принада, Проня, Фермерка, Мальованка, Лютесценс 48-13. Відносно низькі розбіжності значень коефіцієнтів регресії вивчених показників пояснюються тим, що до завершення конкурсного випробування доходять лінії, які показують стабільно високі за роками урожайність та якість зерна. Методом кластерного аналізу вивчені сорти були об'єднані у 5 основних груп за рівнем прояву вивчених ознак.

Ключові слова: пшениця м'яка озима, пластичність, стабільність, врожайність, вміст білка, сила борошна 
K.Yu. Suvorova

PhD of Biological Sciences, Senior researcher of Plant Production, Institute named after V.Ya. Yuriev NAAS (Kharkiv), Ukraine V.Z. Iodkovskyi

Research of Plant Production, Institute named after V.Ya. Yuriev NAAS (Kharkiv), Ukraine

O.Yu. Leonov

Doctor of Agricultural Sciences, Senior Researcher, Head of the Laboratory of Plant Production, Institute named after V.Ya. Yuriev NAAS (Kharkiv), Ukraine

Z.V. Usova

PhD of Agricultural Sciences, Senior Researcher, Leading Research of Plant Production, Institute named after V.Ya. Yuriev NAAS (Kharkiv), Ukraine

O.0. Skrypnyk

Junior Researcher of Plant Production, Institute named after V.Ya. Yuriev NAAS (Kharkiv), Ukraine

\section{EVALUATION OF WINTER WHEAT VARIETIES BY ECOLOGICAL PLASTICITY AND STABILITY OF VALUABLE CHARACTERISTICS}

Common winter wheat varieties and lines (Plant Production Institute named after V.Ya. Yuriev NAAN breeding) were tested for plasticity and stability on yield, protein content, and flour strength. The regression analysis method (Eberhart S.A. and Russell W.A.) was applied to determine the plasticity and stability. A cluster analysis was used to group winter wheat samples according to yield and flour strength depending on growing conditions. It consists of determining the number of clusters by the Ward method with the scales of Euclidean distances of 25-45\% and their subsequent analysis by the $K$-means method when choosing the initial centers of clusters by distance maximizing. According to the statistical analysis of stability and plasticity (regression coefficient and coefficient of variation), all samples belonged to plastic varieties. A high level of yield plasticity, close to checks Podolianka and Smuhlianka, was noted for Doskonala, Alians, Zdobna, Metelytsia kharkivska, Haiok, and a low level for Zapashna, Erythrospermum 832-14, Malovanka, Krasa laniv. These varieties provided a consistently high yield as the standard Bunchuk. Varieties and lines were divided into 4 clusters according to cluster analysis based on yield. The first cluster included high-yielding plastic varieties of intensive type Mavka IR, Pronia, Lutescens 48-13. Cluster 2 included plastic varieties of the Bunchuk level and highly plastic varieties of the Smuhlianka level, cluster 3 - stable medium-yielding varieties, cluster 4 - plastic, medium-yielding varieties (Yednist and Podolianka type). Analysis of the protein content in grain showed that the varieties with a high value of the indicator belonged to the group of plastic samples of the Bunchuk level: Pronia, Harmonika, Prynada, Pryvitna, Pryvablyva, Doridna. The varieties of this group are the universal type of use varieties, which, regardless of the growing conditions, form high-quality grain of 1-2 classes. High yield of the Podolianka, Yednist level, and a stable value of protein content was observed for Zapashna, Alians, Rozkishna, Lutescens 48-13, Erythrospermum 832-14. High indicators of flour strength from 242 alveograph units up to 281 ones inherent in the varieties of the Smuhlianka group: Korovaina, Prynada, Pronia, Fermerka, Malovanka, Lutescens 48-13. Relatively small differences between the values of the regression coefficients and variations of the studied indicators are explained by the fact that lines in the competitive variety testing were characterized by consistently high indicators of yield and grain quality parameters. The studied varieties were combined into 5 main groups according to the level of traits by the method of cluster analysis. Keywords: common winter wheat, plasticity, stability, yield, protein content, flour strength

Постановка проблеми. Створення більш урожайних сортів пшениці м'якої озимої залишається одним з головних чинників збільшення валових зборів зерна. Одночасно зростають та розширюються вимоги споживачів до продуктів, які виробляються із зерна пшениці, дуже велике значення надається вихідному матеріалу з підвищеною якістю зерна. 3 огляду на це, а також на те що нині спостерігається збільшення нестабільності погодних умов та флуктуація клімату найбільш конкурентоспроможними будуть сорти з високим адаптивним потенціалом. Досвід вітчизняної та світової селекції свідчить, що у процесі створення сортів пшениці озимої велике, а в деяких випадках вирішальне значення має наявність вихідного матеріалу, який поєднує продуктивність з адаптивними ознаками [1].

Для вірного розміщення сортів по регіонах, а також вибору технології вирощування важливо знати їхній потенціал адаптивності, який оцінюється за допомогою екологічної пластичності й стабільності. Дані ознаки характеризують особливості пристосування сорту до умов зовнішнього середовища і дають уяву про переваги та недоліки того чи іншого сорту, його поведінки у різних умовах вирощування. Висока чутливість окремих сортів до несприятливих умов вирощування часто звужує ареал їх поширення в інші екологічні зони й обмежує їх загальне розповсюдження. Саме тому розширення норми реакції сортів на умови довкілля $€$ основним завданням селекції, особливо для регіонів зі стресовими гідротермічними умовами [2-6].

Аналіз останніх досліджень і публікацій. Вивчення генетичних відмінностей колекційного матеріалу різного еколого-географічного походження за різних умов навколишнього природного середовища дає можливість створити нові сорти з підвищеною екологічною пластичністю та стабільністю, розраховані на максимальну реалізацію свого потенціалу продуктивності. Проведення статистичного аналізу на стабільність-пластичність сприяло виділенню генотипів різних сільськогосподарських культур: пшениці м'якої озимої $[1,4]$, льону олійного [5], гороху [6], пшениці м'якої ярої [7], ріпаку ярого [8], соняшнику [9], сої [10], та інших культур інтенсивного типу 3 позитивною реакцією на поліпшення умов вирощування. Дослідження з виявлення стабільності та пластичності ознак дозволяють виявити дію абіотичних і біотичних чинників певного середовища на генотип і встановити ступінь їх впливу на ріст, розвиток, урожайність сортів [11-15].

Використання кластерного аналізу для ідентифікації генотипів наближає до створення теоретичної і практичної моделі сорту пшениці озимої, в якої сприятливе співвідношення кількісних і якісних ознак дає можливість протистояти негативним впливам навколишнього середовища та формувати високу продуктивність $[7,16]$.

Мета дослідження. Визначити пластичність і стабільність сортів та перспективних ліній пшениці м'якої озимої селекції Інституту рослинництва ім. В.Я. Юр'єва НААН за врожайністю, вмістом білка в зерні, силою борошна, встановити стабільність прояву цих ознак в умовах різних років вирощування.

Методика досліджень. Польові досліди проводились упродовж 2015-2018 років на селекційних полях Інституту рослинництва імені В.Я. Юр'єва НААН. Сорти пшениці м'якої озимої висівали у конкурсному сортовипробуванні після чистого пару. Сівбу проводили селекційною сівалкою Клен 1,5 С. Облікова площа ділянки 10 м2, повторність 4-разова.

До аналізу залучено 27 зразків селекції Інституту рослинництва імені В.Я. Юр'єва НААН (IP) з них: 19 сортів занесених до Державного Реєстру сортів рослин, придатних для поширення в Україні на 2021 р. (Дорідна, Досконала, Приваблива, Альянс, Розкішна, Статна, Запашна, Фермерка, Здобна, Привітна, Гармоніка, Патріотка, Краса ланів, Принада, Вигадка, Коровайна, Гайок, Метелиця харківська, Проня) [17]; 2 сорти, які проходять кваліфікаційну експертизу (Мавка IP, Мальованка); 2 перспективні лінії (Еритроспермум 832-14 (Еритр. 832- 
14), Лютесценс 48-13 (Лют. 48-13)); 4 стандарти (Подолянка, Смуглянка, Бунчук, Єдність).

Для вивчення особливостей прояву стабільності та пластичності за врожайності сортів, вмісту білка, сили борошна провели регресійний аналіз за методикою С.А. Еберхарта, В.А. Рассела (Eberhart S.A., Russell W.A.) [18] Реакцію сорту на зміну умов середовища (пластичність) визначали за коефіцієнтом лінійної регресії b [19]. Для групування зразків за ознаками урожайності та сили борошна у зв'язку зі зміною умов вирощування використали спосіб, який полягає у визначенні кількості кластерів методом Варда з масштабами евклідових відстаней 25-45 \% та подальшому їх аналізі методом K-середніх при виборі початкових центрів кластерів максимізацією відстаней [15]. Результати досліджень опрацьовувались за допомогою статистичних методів, групування проводили за допомогою кластерного аналізу, який здійснювали на пакеті STATISTICA 6.1/ SN BXXR502C631824NET3.

Погодні умови років досліджень суттєво вплинули на формування врожайності сортів. Кожному року досліджень притаманна своя специфіка формування рівня ознаки у зразків (рис. 1). Сприятливі погодні умови сформували максимальну врожайність у середньому 8,22 т/га у 2015 р. і 8,60 т/га у 2017 р. Осінь 2015 р. була над- звичайно посушливою. На дослідному полі після чистого пару неповні сходи отримано в першій декаді жовтня. Зимовий період 2015/2016 рр. вирізнявся підвищеним температурним режимом, на посівах, де з осені не отримано сходів, на кінець лютого спостерігали початкову фазу сходів. Весняно-літній період був теплим та достатньо зволоженим, кількість опадів на 50 \% перевищувала норму. Рівень інфекційного фону хвороб пшениці озимої та збіг несприятливих погодних умов для розвитку та формуванню врожаю знизили цей показник до 5,63 т/га у 2016 році.

Результати дослідження та їх обговорення. На основі статистичного аналізу були отримані показники пластичності (b) та стабільності (CV) (табл. 1). Згідно виконаного аналізу усі сорти та лінії селекції IP за показниками урожайності (т/га), вмісту білка (\%) та силі борошна (од. а.) належать до групи пластичних сортів. До групи пластичних сортів за ознакою врожайність у яких коефіцієнт регресії дорівнює 1 , а коефіцієнт варіації знаходиться у межах 20 \% відносяться сорти: Статна, Фермерка, Привітна, Принада, Коровайна, Мавка IP, лінія Лютесценс 48-13 та стандарт Єдність. Зміна врожайності цих сортів більшою мірою визначалася погодними умовами.

\section{Кількість опадів за період досліджень, мм}

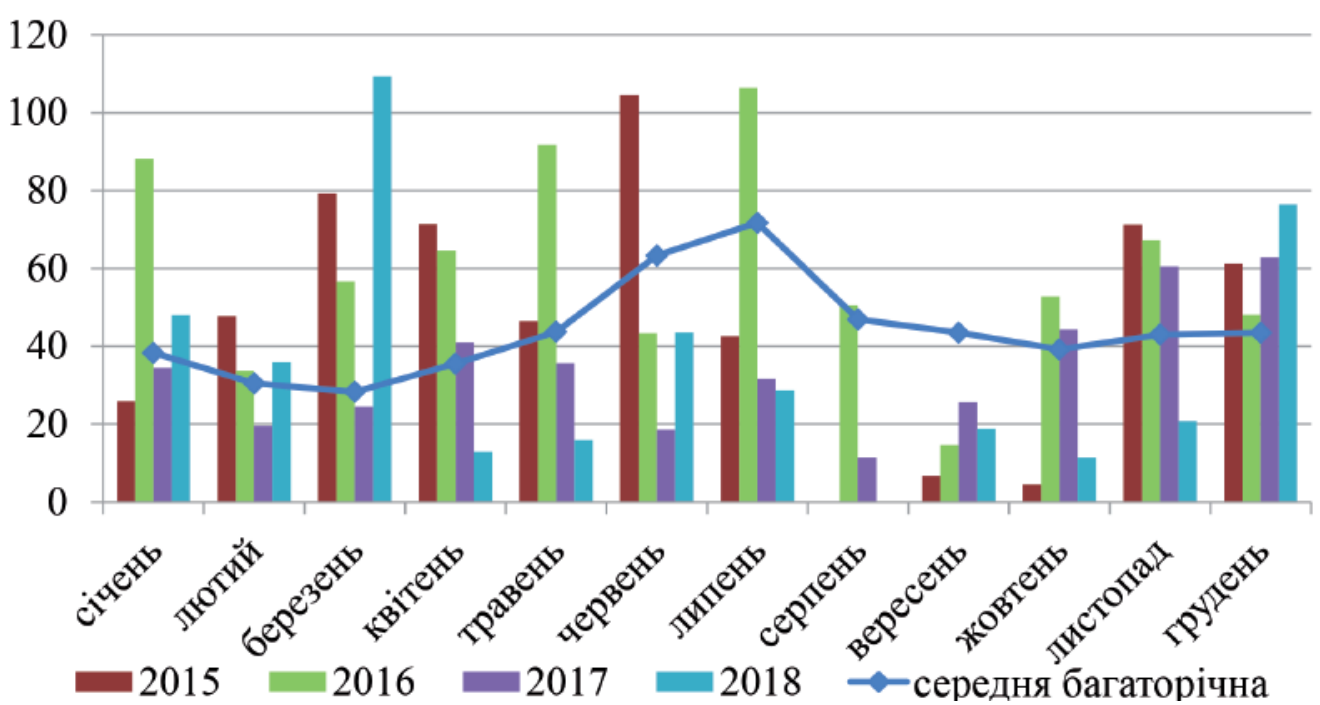

Середньодобова температура повітря за місяцями, ${ }^{\circ} \mathrm{C}$

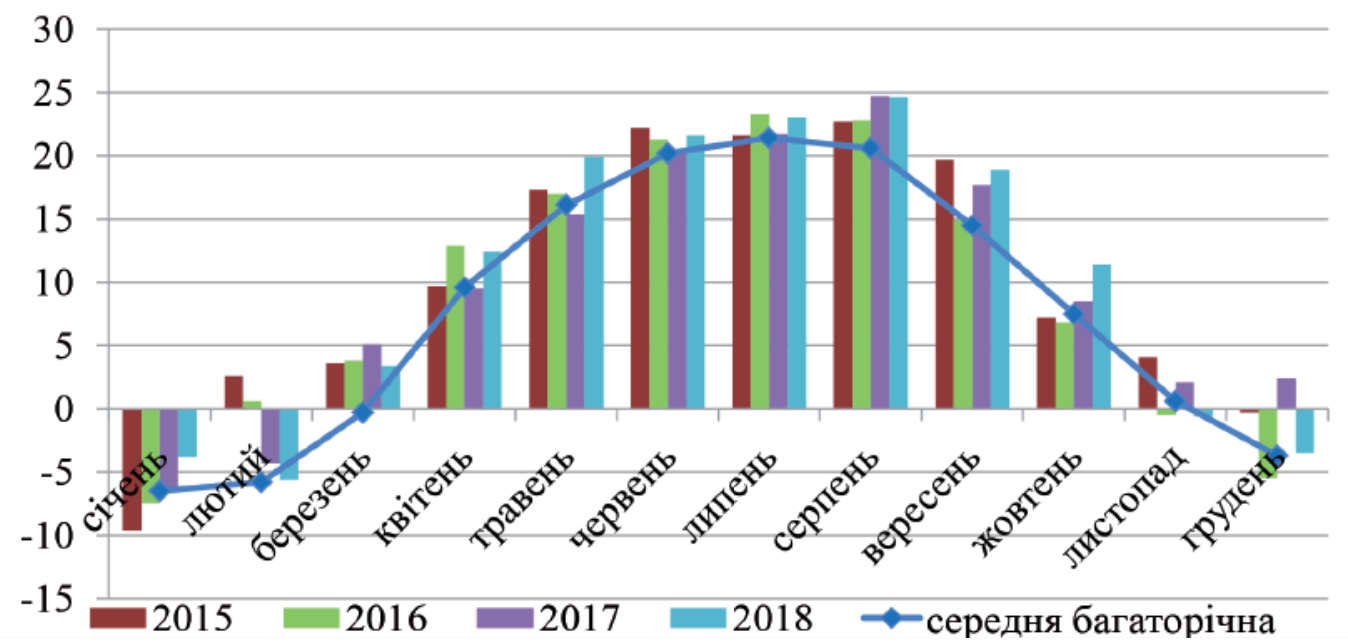

Рис. 1 Кількість опадів і середньодобова температура повітря, 2015-2018 рр. 
Високий рівень пластичності близький до рівня стандартів Подолянка і Смуглянка за цією ознакою притаманний сортам: Досконала, Альянс, Здобна, Метелиця харківська, Гайок. При значенні коефіцієнту регресії значно меншому за одиницю й невисокому значенні CV сорти Запашна, Еритроспермум 832-14, Мальованка, Краса ланів були низькопластичними, але забезпечували стабільно досить високий урожай на рівні стандарту Бунчук $(7,70$ т/га). Методом кластерного аналізу зразки були згруповані за рівнем прояву вивчених ознак. За масштабами евклідових відстаней при об'єднанні методом Варда отримано 4 кластери (рис. 2, нумерація кластерів зліва на право).

Стабільність та пластичність показників урожайності та якості зерна зразків пшениці озимої, 2015-2018 pp.

\begin{tabular}{|c|c|c|c|c|c|c|c|c|c|c|c|c|}
\hline \multirow[b]{2}{*}{ Cорт } & \multicolumn{4}{|c|}{ Урожайність } & \multicolumn{4}{|c|}{ Вміст білка } & \multicolumn{4}{|c|}{ Сила борошна } \\
\hline & $\underset{\text { т/га }}{\text { середн }}$ & $\begin{array}{c}\text { відхилення } \\
\text { від } \\
\text { середньої }\end{array}$ & $\boldsymbol{b}$ & $C V, \%$ & $\underset{\%}{\text { середнє }}$ & \begin{tabular}{|c|} 
відхилення \\
від \\
середньої
\end{tabular} & $\boldsymbol{b}$ & $c V, \%$ & \begin{tabular}{|c} 
середнє, \\
од. ал.
\end{tabular} & $\begin{array}{c}\text { відхилення } \\
\text { від } \\
\text { середньої }\end{array}$ & $\boldsymbol{b}$ & $C V, \%$ \\
\hline Подолянка & 7,41 & 0,02 & 1,10 & 20,38 & 11,91 & $-0,30$ & 1,08 & 10,57 & 225,75 & $-2,16$ & 1,33 & 34,12 \\
\hline Дорідна & 6,65 & $-0,74$ & 0,98 & 20,29 & 12,67 & 0,46 & 0,99 & 9,69 & 207,75 & $-20,16$ & 1,54 & 42,20 \\
\hline Досконала & 7,53 & 0,14 & 1,23 & 21,81 & 12,51 & 0,31 & 0,85 & 7,83 & 191,25 & $-36,66$ & 1,18 & 38,28 \\
\hline Приваблива & 7,26 & $-0,13$ & 0,87 & 17,01 & 12,31 & 0,10 & 1,00 & 9,98 & 227,25 & $-0,66$ & 1,52 & 37,63 \\
\hline Альянс & 7,24 & $-0,15$ & 1,35 & 24,91 & 11,92 & $-0,29$ & 0,89 & 8,88 & 225,75 & $-2,16$ & 1,96 & 51,39 \\
\hline Розкішна & 7,46 & 0,07 & 0,96 & 17,65 & 12,06 & $-0,15$ & 1,15 & 10,48 & 217,25 & $-10,66$ & 0,99 & 29,14 \\
\hline Статна & 6,93 & $-0,46$ & 1,06 & 21,66 & 12,05 & $-0,16$ & 1,48 & 13,98 & 220,75 & $-7,16$ & 0,56 & 14,12 \\
\hline Запашна & 7,62 & 0,23 & 0,69 & 13,27 & 11,61 & $-0,59$ & 1,05 & 10,11 & 224,00 & $-3,91$ & 0,42 & 25,26 \\
\hline Фермерка & 7,18 & $-0,21$ & 0,98 & 20,11 & 12,06 & $-0,14$ & 0,91 & 9,01 & 248,50 & 20,59 & 1,17 & 29,93 \\
\hline Здобна & 7,60 & 0,21 & 1,19 & 21,00 & 11,83 & $-0,38$ & 1,37 & 13,24 & 206,00 & $-21,91$ & 0,53 & 37,32 \\
\hline Привітна & 6,79 & $-0,60$ & 1,01 & 22,25 & 12,93 & 0,73 & 0,99 & 8,72 & 207,75 & $-20,16$ & 1,66 & 44,30 \\
\hline Гармоніка & 7,34 & $-0,05$ & 0,93 & 17,97 & 12,42 & 0,21 & 1,05 & 9,95 & 229,00 & 1,09 & 2,10 & 54,20 \\
\hline Патріотка & 6,69 & $-0,70$ & 0,77 & 16,89 & 12,41 & 0,20 & 1,08 & 11,23 & 238,50 & 10,59 & 0,36 & 29,67 \\
\hline Краса ланів & 7,09 & $-0,30$ & 0,81 & 16,54 & 12,28 & 0,07 & 1,18 & 11,53 & 227,75 & $-0,16$ & 1,03 & 27,38 \\
\hline Принада & 7,01 & $-0,38$ & 1,04 & 20,51 & 13,11 & 0,90 & 0,91 & 8,17 & 264,75 & 36,84 & 1,36 & 37,34 \\
\hline Вигадка & 7,15 & $-0,24$ & 0,88 & 16,96 & 12,18 & $-0,03$ & 0,86 & 7,79 & 220,75 & $-7,16$ & 0,66 & 17,86 \\
\hline Коровайна & 7,17 & $-0,22$ & 1,07 & 21,10 & 12,55 & 0,35 & 0,82 & 7,81 & 258,25 & 30,34 & 0,69 & 18,96 \\
\hline Смуглянка & 7,30 & $-0,09$ & 1,14 & 21,28 & 12,24 & 0,03 & 0,48 & 4,30 & 242,00 & 14,09 & 1,50 & 34,48 \\
\hline Бунчук & 7,70 & 0,31 & 0,81 & 14,76 & 12,48 & 0,27 & 0,90 & 7,98 & 229,00 & 1,09 & 0,45 & 12,26 \\
\hline Єдність & 7,43 & 0,04 & 1,06 & 19,53 & 11,56 & $-0,64$ & 0,99 & 9,57 & 232,25 & 4,34 & 0,08 & 10,50 \\
\hline Гайок & 7,58 & 0,19 & 1,19 & 21,17 & 12,33 & 0,12 & 1,18 & 10,55 & 199,50 & $-28,41$ & 0,52 & 29,42 \\
\hline Метелиця & 7,53 & 0,14 & 1,37 & 24,54 & 11,70 & $-0,51$ & 1,35 & 12,69 & 157,00 & $-70,91$ & 0,59 & 21,38 \\
\hline Проня & 8,18 & 0,79 & 0,95 & 15,96 & 12,48 & 0,27 & 0,82 & 8,72 & 247,00 & 19,09 & 1,03 & 26,10 \\
\hline Мавка IP & 8,26 & 0,87 & 0,99 & 16,61 & 11,64 & $-0,56$ & 0,45 & 4,47 & 230,50 & 2,59 & 0,93 & 24,89 \\
\hline Мальованка & 7,65 & 0,26 & 0,81 & 14,84 & 12,31 & 0,11 & 0,66 & 6,40 & 281,00 & 53,09 & 0,80 & 16,49 \\
\hline Еритр.832-14 & 7,64 & 0,25 & 0,72 & 12,88 & 11,93 & $-0,28$ & 1,25 & 11,77 & 252,00 & 24,09 & 1,07 & 30,06 \\
\hline Лют. 48-13 & 8,07 & 0,68 & 1,05 & 17,55 & 12,08 & $-0,12$ & 1,27 & 11,48 & 242,25 & 14,34 & 0,98 & 33,12 \\
\hline Середнє & 7,39 & & & & 12,20 & & & & 227,91 & & & \\
\hline
\end{tabular}

До першого кластеру увійшли високоврожайні пластичні сорти інтенсивного типу Мавка IP (8,26 т/га), Проня (8,18 т/га), лінія Лютесценс 48-13 (8,06 т/га). Другий кластер виявився найчисельнішим. Це пластичні сорти з врожайністю на рівні стандарту Бунчук (7,70 т/га): Мальованка, Запашна, лінія Еритроспермум 832-14 та сорти з високою пластичністю на рівні стандарту Смуглянка і врожайністю від 7,18 т/га до 7,69 т/га: Запашна, Фермерка, Розкішна, Метелиця харківська, Альянс, Гайок, Здобна, Досконала. Сорти другого кластеру на графіку (рис. 3) розташовувались у межах середньостатистичної лінії. До третього кластеру відносяться сорти, які незалежно від погодних умов року були стабільними за врожайністю, хоча дещо поступалася стандартам (від 6,65 т/га до 7,34 т/га): Краса ланів, Гармоніка, Привітна, Патріотка, Статна, Дорідна. До четвертого кластеру увійшли пластичні середньоврожайні сорти на рівні стандартів Єдність і По- долянка: Вигадка, Принада, Приваблива.

Відомо, що технологічні показники якості зерна (вміст білка в зерні і сила борошна) мають обернену кореляцію з урожайністю, яка в свою чергу залежать від умов навколишнього середовища: кількості опадів, температури у період наливу зерна, вмісту доступних для рослин азотних речовин у ґрунті [19-21]. Аналіз вмісту білка в досліджуваних зразках пшениці озимої за результатами визначення коефіцієнту регресії та розподілу за кластерним аналізом показав, що пластичними сортами 3 найвищим серед вивчених зразків вмістом білка в зерні $\epsilon$ сорти: Проня, Гармоніка, Принада, Привітна, Приваблива, Дорідна, стандарт Бунчук. Рівень вмісту білка в зерні змінювався в середньому за 4 роки від 12,3 \% до 12,9\%, ці сорти за евклідовими відстанями належали до 2 кластеру (рис. 4). Сорти цієї групи віднесено до універсального типу використання, рекомендується їх сіяти після непа- 


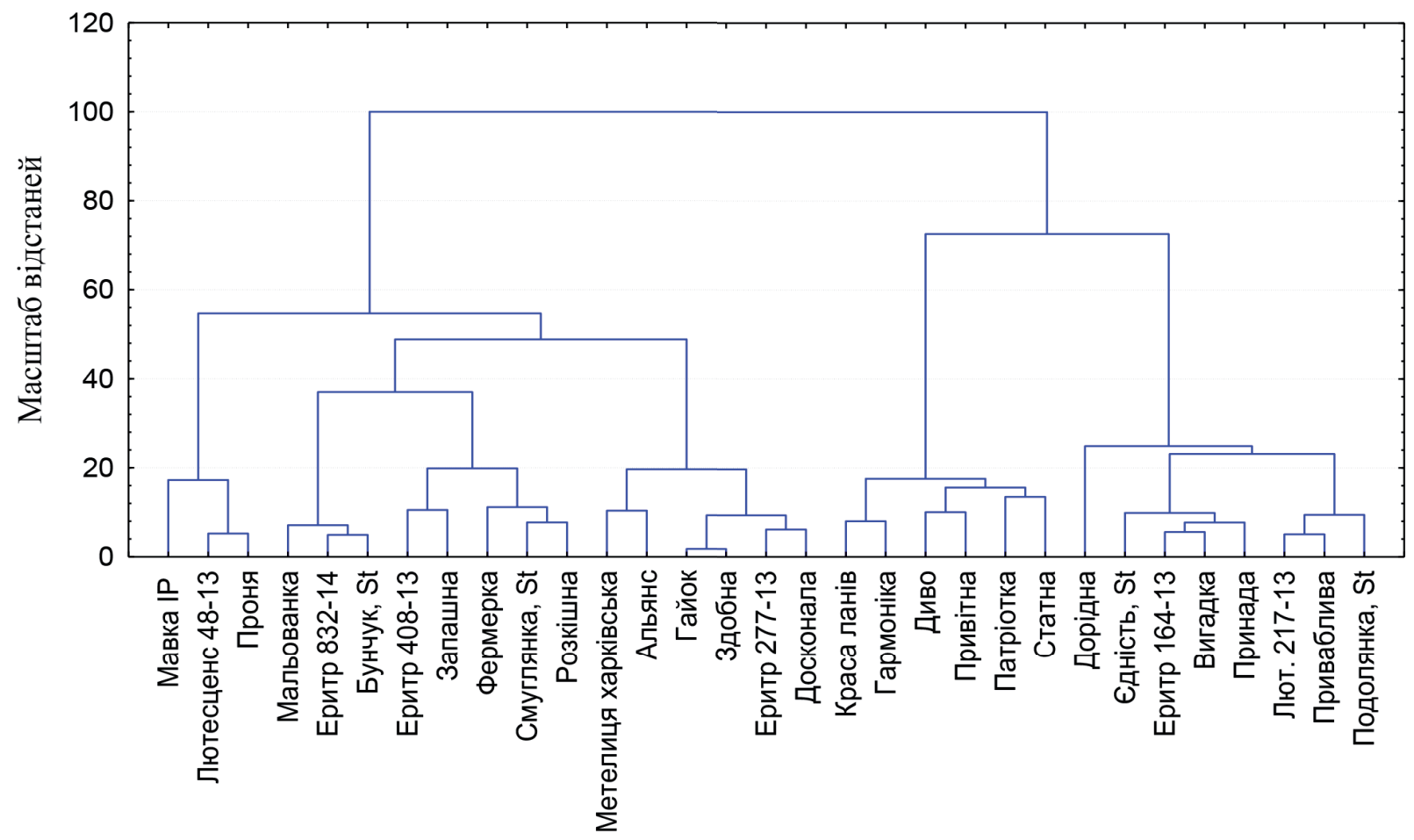

Рис. 2 Групування зразків пшениці м'якої озимої за урожайністю, 2015-2018 рр., (евклідові відстані, метод Варда)

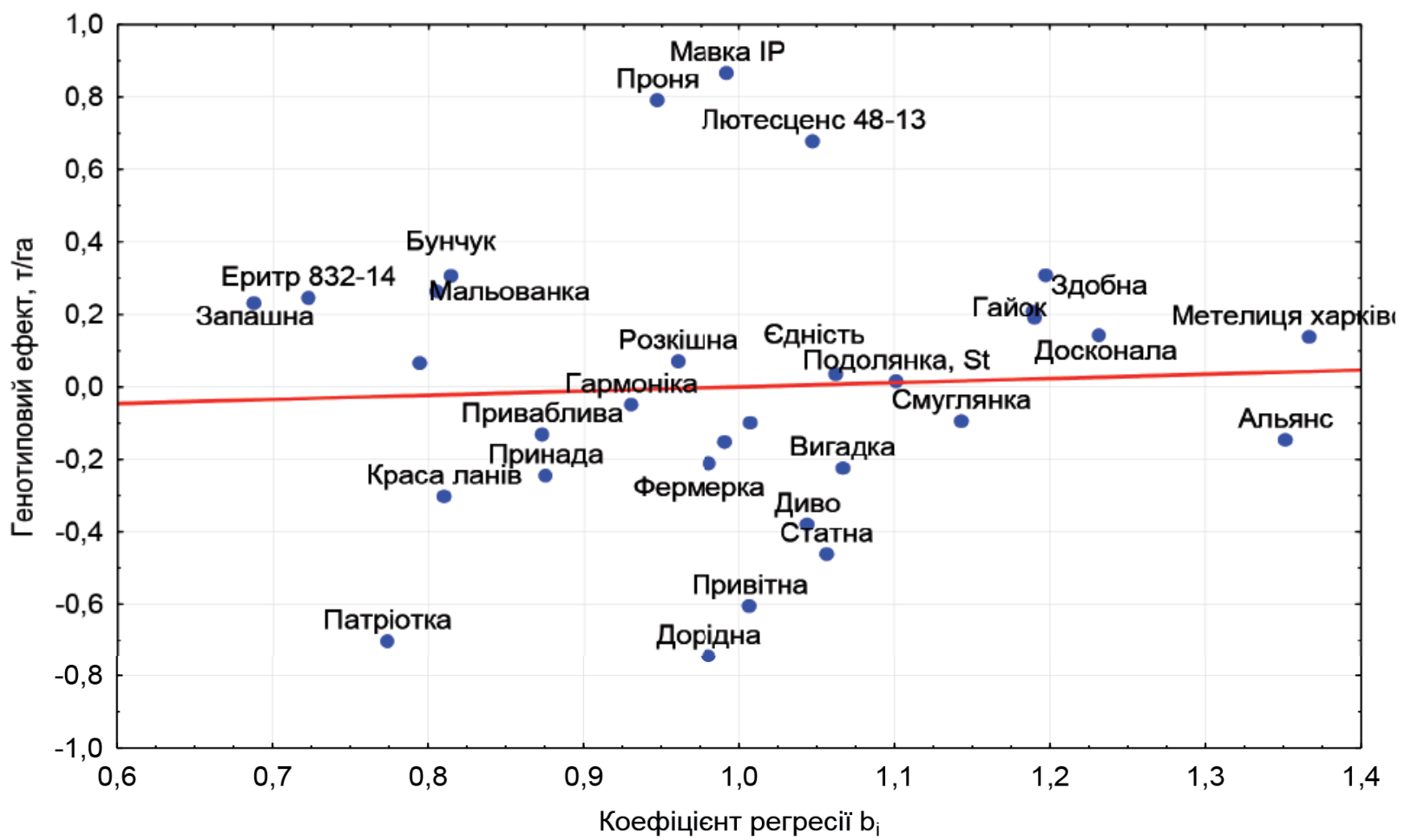

Рис. 3 Зв'язок генотипового ефекту і коефіцієнту регресії показника врожайності зразків пшениці м'якої озимої в залежності від екологічних умов, 2015-2018 рр.

рових попередників, бо незалежно від умов вирощування, вони формують зерно 1 або 2 класу.

За ознакою вміст білка до першого кластеру (низький коефіцієнт регресії і невелике значення CV) ввійшли сорти рівня стандарту Смуглянка ( $b=0,48, \mathrm{CV}=4,30 \%)$ : Вигадка (b=0,86, $\mathrm{CV}=7,79 \%)$ і Мальованка $(\mathrm{b}=0,66$, $\mathrm{CV}=6,40 \%)$. Високе значення коефіцієнту регресії 1,48 , 1,37 і 1,35, але невисоке значення вмісту білка $12,0 \%$, $11,8 \%, 11,7$ \%, мали відповідно зразки Статна, Здобна, Метелиця харківська, (кластер 3). Сорти Запашна, Альянс, Розкішна, лінії Лютесценс 48-13, Еритроспермум
832-14, стандарти Подолянка та Єдність $€$ пластичними, із стабільно невеликим вмістом білка від 11,6 \% до 12,1 $\%$, розташувалися вони у 4 кластері.

Погодні умови 2015 року сприяли широкому діапазону змін вмісту білка. Згідно графіку залежності вмісту білка від погодних умов років вирощування група сортів 3 кластеру (Гайок, Краса ланів, Патріотка, Фермерка, Метелиця харківська, Здобна, Статна) мала самий низький рівень білка - від 9,9 \% до 11,2 \%, сорти 2 кластеру (Бунчук, Коровайна, Досконала, Принада, Привітна, Дорідна) самі високі значення - від 12,5 \% до 


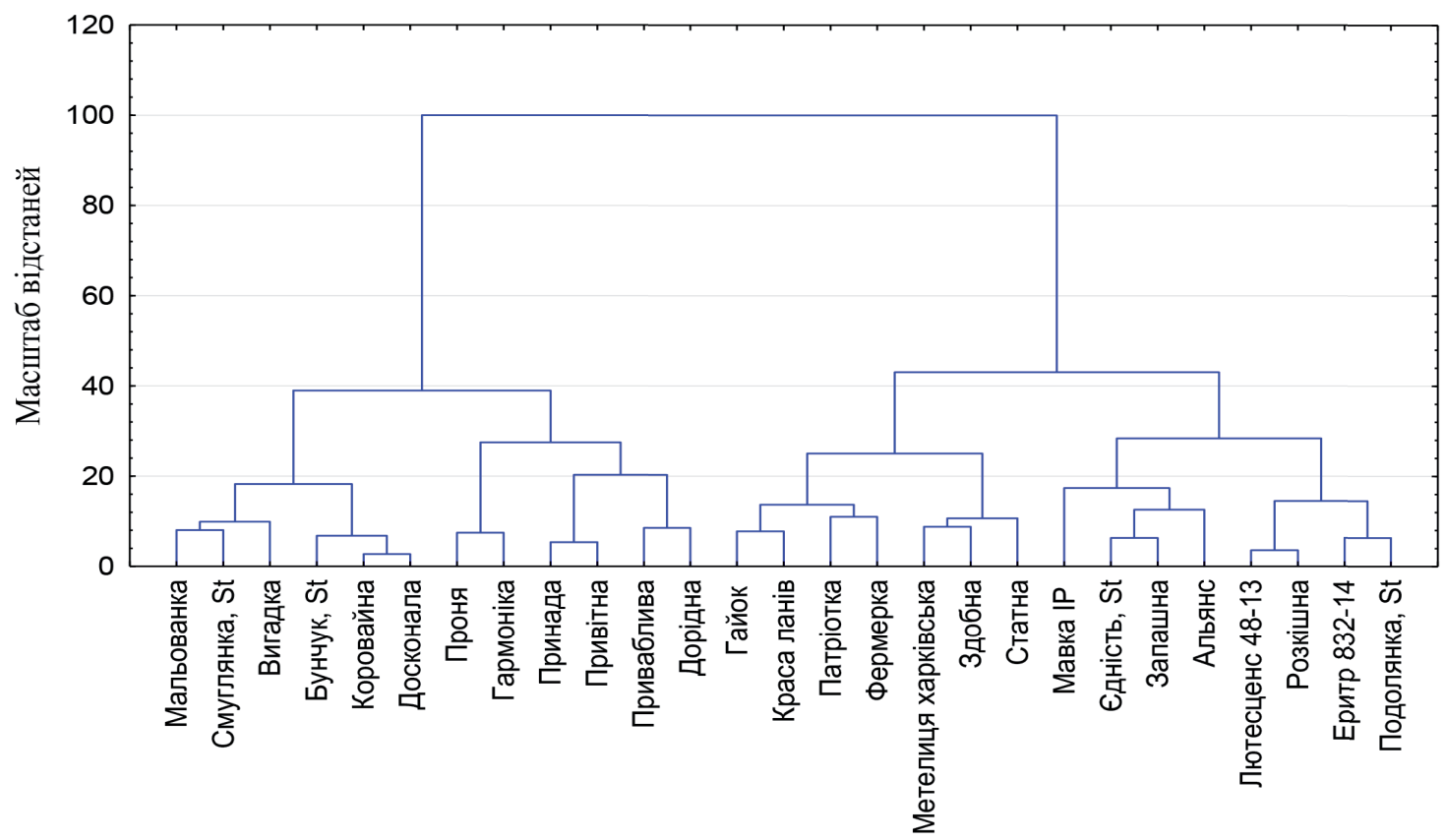

Рис. 4 Групування зразків пшениці м'якої озимої за вмістом білка в зерні, 2015-2018 рр. (евклідові відстані, метод Варда)

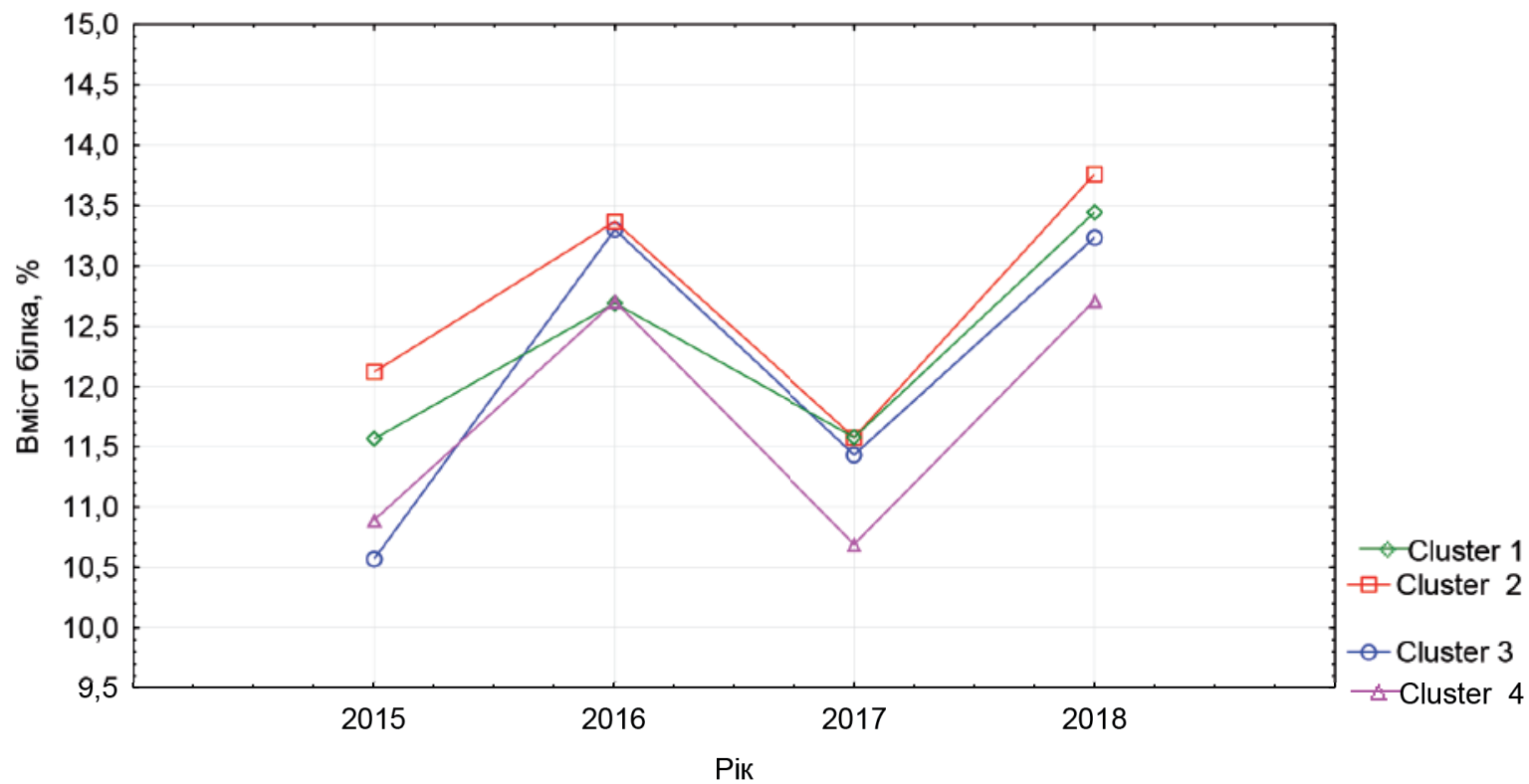

Рис. 5 Вміст білка у зерні зразків пшениці озимої різних кластерів в залежності від умов року вирощування, 2015-2018 pp., \%

13,1\%. У 2016 році показники 2 і 3 кластерів збігалися і мали високий вміст білка (рис. 5).

Однаково високий максимальний показник вмісту білка 2 і 3 кластеру спостерігався у 2017 році, а в найсприятливішому для формування високої якості зерна у 2018 році сорти 2 кластеру мали перевагу над всіма кластерами, а 3 кластер займав проміжне положення. Сорти 4 кластеру (Мавка IP, Запашна, Альянс, Розкішна, Лютесценс 48-14, Еритроспермум 832-14, стандарти Єдність і Подолянка) мали стабільно низькі показники не залежно від року вирощування.

Отже, за ознакою вміст білка зразки, які ввійшли до 2 кластеру характеризуються високим, порівняно 3 іншими кластерами, рівнем прояву показника, а кластеру 4 - найнижчим, водночас зразки кластеру 1 - мали менші зміни ознаки за роками, а кластеру 3 - вищі.

За силою борошна згідно кластерного аналізу сорти розділились на 5 кластерів (рис. 6). До 1 кластеру увійшли 2 сорти з самими високими значеннями коефіцієнтів регресії: Гармоніка $(b=2,10)$ і Альянс $(b=1,96)$. До пластичних сортів належать два наступні кластери другий і третій. До другого кластеру з високою силою борошна від 242 од. а. до 281 од. а. близькою до стандарту Смуглянка належать сорти Коровайна, Принада, Проня, Фермерка, Лютесценс 48-13, Мальованка. До третього кластеру пластичні сорти з середнім значенням сили борошна від 207 од. а. до 227 од. а.: Мавка IP, Розкішна, Досконала, Приваблива, Привітна, Дорідна. Низькопластичними з низькою силою борошна від 157 од. а. до 224 од. а. були сорти 4 кластеру: Метелиця харківська, Гайок, Здобна, Запашна. Сорти 5 кластеру Вигадка, Статна, Патріотка $€$ низькопластичними, але з середньою силою борошна на рівні Єдності (232 од. а.) і Бунчука (229 од. а.), а сорт Краса ланів та лінія Еритроспермум 832-14 на рівні Подолянки (226 од. а.).

Згідно графіку залежності сили борошна від умов року (рис. 7) у 2015 році між кластерами була велика розбіжність за силою борошна до 60 од. а., оскільки був 
і великий розрив між мінімальним (144 од. а.) і максимальними (392 од. а.) значеннями. У 2016 р. показник сили борошна знизився, а у наступні роки поступово зростав, різниця між кластерами сягала вже до 10 од. а. Виключення становив 1 кластер, розподіл якого мав вигляд ламаної. У сортів 1 кластеру (Гармоніка, Альянс) середній показник сили борошна у 2016 і у 2017 роках упав майже до мінімального значення (92 од. а.), а в 2018 році різко піднявся до максимального значення (198 од. а.) випередив всі кластери на 100 од. а. Коефіцієнти регресії цього кластеру $(b=2,10$ і $b=1,96)$ підтвердили високу пластичність цих сортів. Навпаки сорти 4 кластеру (Метелиця харківська, Гайок, Здобна, Запашна) належали до низькопластичних за коефіцієнтом регресії. Цей кластер мав саму низьку силу борошна у 2015 році (від 144 од. а. до 196 од. а.), у 2016 році середню, а у 2017 році максимальний відрив від інших кластерів на 60 од. а. (262 од. а. до 294 од. а.) у сторону збільшення, у 2018 році - проміжні показники. Самим стабільним за показниками сили борошна виявився 5 кластер до якого увійшов стандарт Подолянка (Патріотка, Краса ланів, Еритроспермум

\section{2-14)}

Отже за показником сила борошна, кластери 1 і 2 об'єднали найбільш пластичні сорти (226 од. а.), а кластер 5 - стабільні (230 од. а.). Високу силу борошна мали пластичні сорти: Мальованка, Коровайна, Лютесценс 48-13, Принада, Проня, Фермерка, Мавка IP, стандарт Смуглянка. Стабільно середню силу борошна мали сорти: Вигадка, Статна, Краса ланів, Метелиця харківська, стандарти Єдність та Бунчук.

Висновки. Проведений статистичний аналіз 27 сортів і ліній селекції IP показав, що за показниками коефіцієнту регресії та варіації вони належать до групи пластичних сортів за показниками урожайності, вмісту білка в зерні та сили борошна. Відносно низькі розбіжності значень коефіцієнтів регресії вивчених показників пояснюються тим, що до завершення конкурсного випробування доходять лінії, які показують стабільно високі за роками показники урожайності та якості зерна. Метод кластерного аналізу дозволив згрупувати сорти за рівнем прояву вивчених ознак, які можна розділити на 5 груп:

1. Високопластичні за урожайністю, вмістом білка і

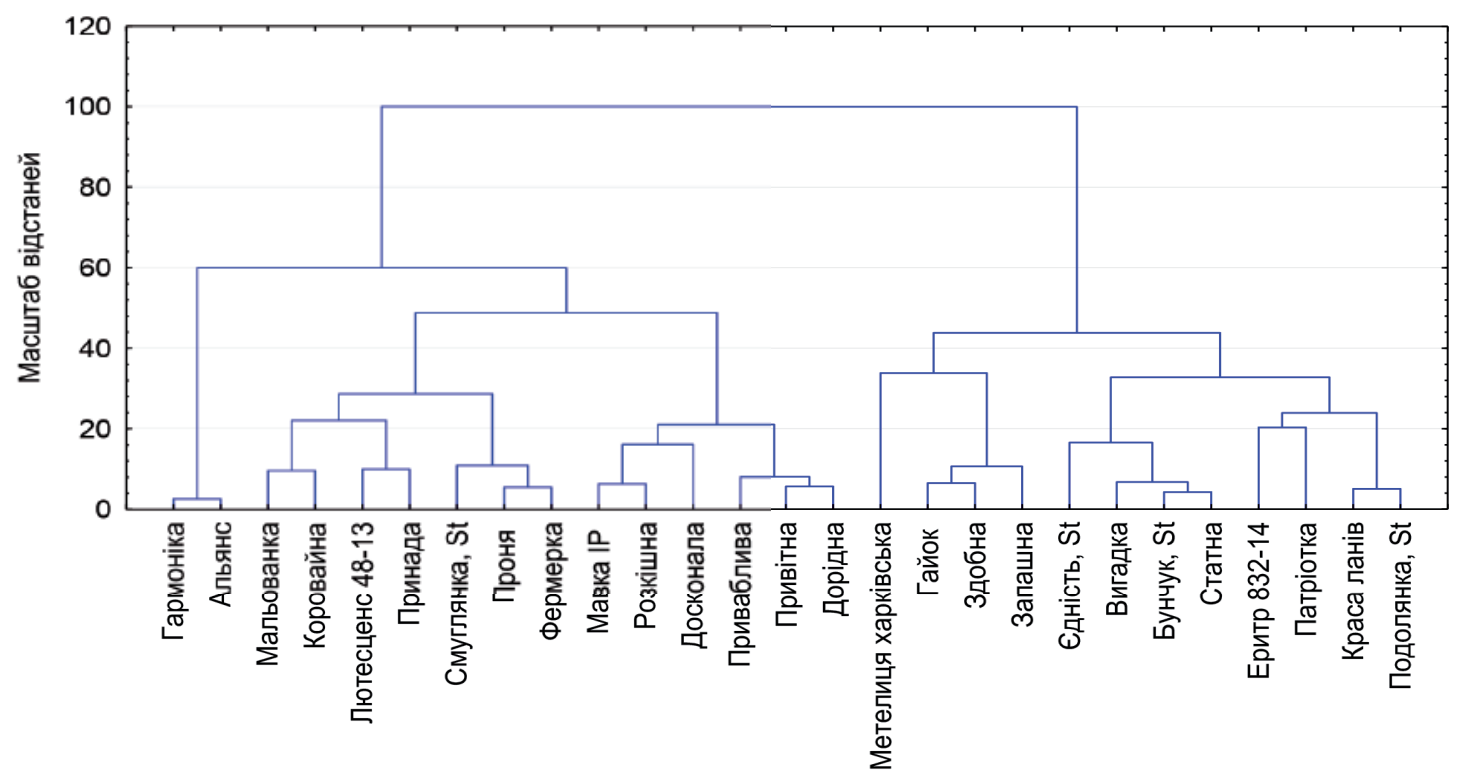

Рис. 6 Групування зразків пшениці м'якої озимої у кластери за силою борошна, 2015-2018 рр. (евклідові відстані, метод Варда)

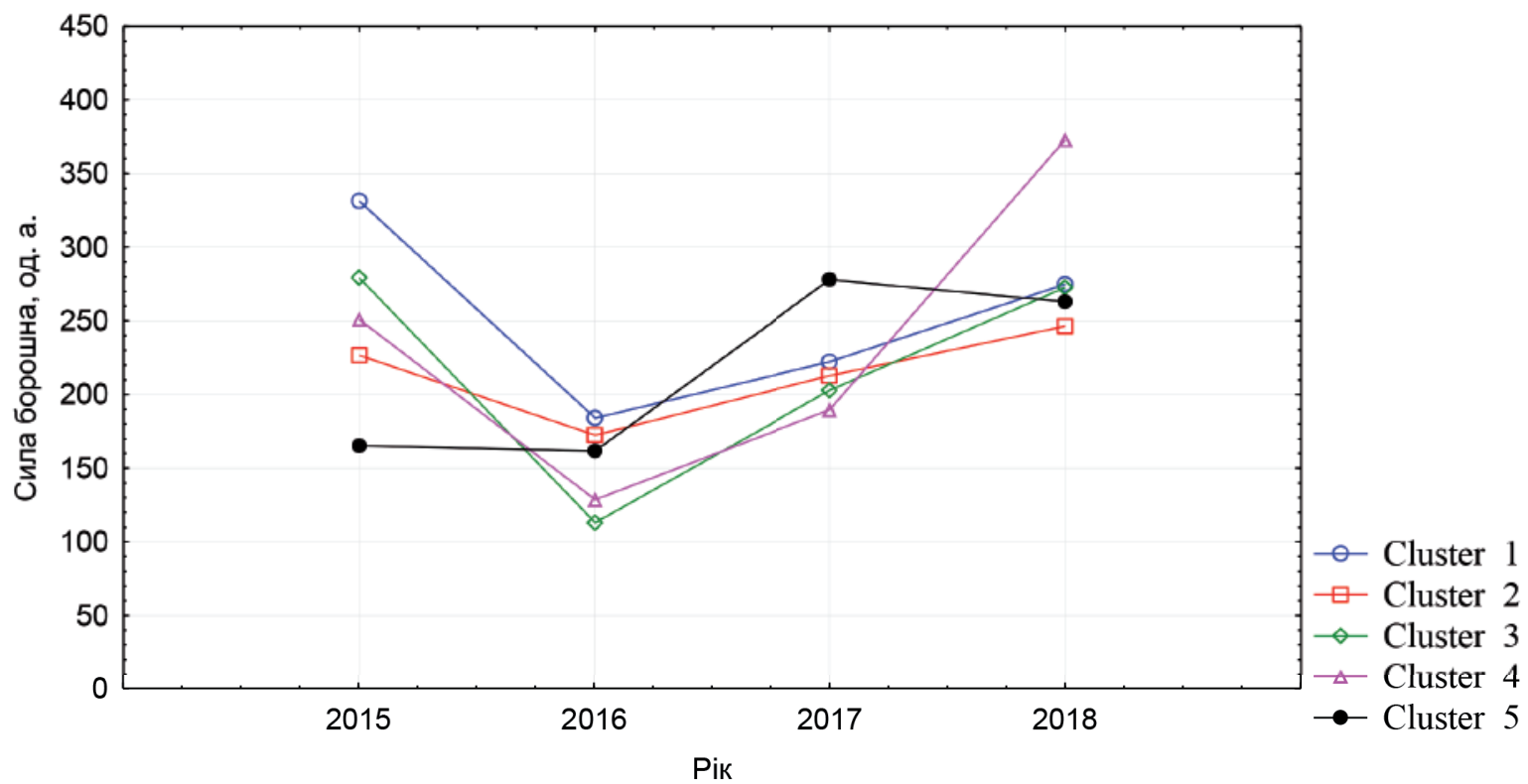

Рис. 7 Сила борошна зразків пшениці м'якої озимої різних кластерів в залежності від умов року вирощування, 2015-2018 pp. 
стабільні за силою борошна: Гайок, Метелиця харківська, Здобна.

2. Сорти подібні до стандарту Подолянка, які пластичні за врожайністю, вмістом білка, високопластичні за силою борошна: Гармоніка, Дорідна, Привітна, Приваблива, Принада, Фермерка.

3. Пластичні за врожайністю, стабільно формують зерно з високими показниками якості незалежно від погодних умов: Проня і Коровайна.

4. Сорти, які істотно реагують на зміну погодних умов, забезпечують стабільні врожаї, мають середній і вище середнього вміст білка й високу силу борошна: Вигадка і Мальованка.

5. Сорти, які істотно реагують на зміну погодних умов, забезпечують стабільні врожаї, стабільно середню силу борошна, але пластичні за вмістом білка: Запашна, Патріотка.

\section{Література}

1. Дубовик Н.С., Кириленко В.В., Дергачов О.Л. Пластичність та стабільність вихідного матеріалу для селекції пшениці м'якої озимої (Triticum aestivum L.). Миронівський вісник. 2015. № 1. С. 36-45.

2. Gilliham M., Able J.A., Roy S.J. Translating knowledge about abiotic stress tolerance to breeding programmers. Plant Journal. 2017. Vol. 90, Iss. 5. P. 898917. doi: 10.1111/tpj.13456

3. Соколенко Н.И., Комаров Н.М. Адаптивные признаки сортообразцов озимой пшеницы мировой коллекции. Таврический вестник аграрной науки. 2019. № 4(20). C. 111-116. DOI 10.33952/ 2542-0720-2019-4-20111-116

4. Василюк П.М. Оцінка стабільності і пластичності показників продуктивності та якості нових сортів пшениці м'якої озимої в умовах Лісостепу України. Сортовивчення та охорона прав на сорти рослин. 2014. № 1. С. 15-18.

5. Янішевський Л.І. Екологічна стабільність і пластичність сортів льону олійного. Вісник Харківського національного аграрного університету : Серія " Рослинництво, селекція і насінництво, плодоовочівництво". 2013. № 1. С.339-343.

6. Присяжнюк О.І., Калюжна Е.А., Українець В.В., Шевченко О.П. Стабільність та пластичність сортів гороху селекції Уладо-Люлинецької Дослідно-Селекційної станції. Цукрові буряки. 2013. №6. С. 19-20.

7. Хоменко С.О., Кочмарський В.С., Федоренко І.В., Федоренко М.В. Стабільність і пластичність колекційних зразків пшениці м'якої ярої за показниками продуктивності. Вісник Уманського національного університету садівництва. 2018. № 1. С. 43-47. DOI: 10.31395/2310-0478-2018-1-43-47

8. Каленська С.М., Мельник А.В., Полекай О.Г. Пластичність та стабільність сучасних сортів і гібридів ріпаку ярого в Лівобережному Лісостепу України. Вісник Сумського національного аграрного університету. Серія : Агрономія і біологія. 2013. Вип. 3 (25). С. 238-241.

9. Димитров С.Г. Стабільність та пластичність сучасних гібридів соняшнику. Збірник наукових праць ННЦ "Інститут землеробства НАAН". 2015. Вип. 3. С. 117-124.

10. Белявская Л.Г., Диянова А.А., Белявский Ю.В. Результаты оценки пластичности и стабильности сортов сои. Universitatea Agrară De Stat Din Moldova Facultatea De Agronomie Lucrări Ştiinţifice. Vol. 52 (1), Chișinău, 2018, P. 190-195.

11. Стариченко В.М., Голик Л.М., Ткачова Н.А., Литус М.В. Оцінка адаптивної здатності та стабільності сортів і ліній в селекції пшениці озимої. Селекція і насінництво. 2014. Вип. 105. С. 77-84. https://doi.org/10.30835/24137510.2014 .42055

12. Петров Л.К. Оценка урожайности, экологической стабильности и пластичности сортов озимой пшеницы в условиях Нижегородской области. Российская сельскохозяйственная наука. 2020. № 3. C 6-9. DOI: 10.31857/ S2500262720030023

13. Сухоруков А.Ф., Сухоруков А.А. Адаптивный потенциал исходного материала озимой пшеницы в Среднем Поволжье. Российская сельскохозяйственная наука. 2019. № 2. С 3-6. https://doi.org/10.31857/S25002627201923-6

14. Бебякин В.М., Розанова Т.А., Злобина Л.Н. Регрессионный анализ пластичности и фенотипической стабильности гибридных популяций яровой мягкой пшеницы по качеству клейковины. Доклады Российской Академии сельскохозяйственных наук. 2013. № 5. С 12-13.

15. Леонов О.Ю. Групування зразків пшениці м'якої за пластичністю та стабільністю прояву кількісних ознак. Генетичні ресурси рослин. 2013. № 13. С. 28-39.

16. Тищенко В.Н., Панченко П.М., Чернышова О.П. Идентификация сортов и селекционных линий пшеницы озимой по сбалансированности количественных признаков с использованием кластерного анализа. Вісник Полтавської державної академії. 2013. № 3. С. 28-36.

17. Державний реєстр сортів рослин, придатних для поширення в Україні на 2021 рік. URL: https://www.sops. gov.ua/reestr-sortiv-roslin

18. Eberhart S.A., Russell W.A. Stability parameters for comparing varieties. Crop Sci. 1966. Vol. 6. P. 36-40. https://doi.org/10.2135/cropsci1966.0011183X000600010 $011 \mathrm{x}$

19. Суркова Л.И., Климашевский Э.Л., Чевжик А.Л и др. Реакция сортов озимой пшеницы на удобрение и наследование признака отзывчивости в системных скрещиваниях. Агрохимия. 1992. №3. С.41-52.

20. Колючий В.Т. Селекція пшениці озимої на якість зерна в Лісостепу України. Селекція і насінництво. 2011. Вип. 100. С. 160-171.

21. Жемела Г.П., Курочка А.О. Вплив попередників на елементи структури врожайності та якість зерна пшениці озимої залежно від сортових властивостей. Вісн. Полтав. держ. аграрної академії. 2012. № 1. С. 33-36.

\section{References}

1. Dubovyk, N.S., Kyrylenko, V.V., Dergachov, O.L. (2015). Plasticity and stability of source material for bread winter wheat breeding (Triticum aestivum L.). Myronivka Bulletin. no. 1. pp. 36-45 (in Ukrainian).

2. Gilliham, M., Able, J.A., Roy, S.J. (2017). Translating knowledge about abiotic stress tolerance to breeding programmers. Plant Journal. Vol. 90, Iss. 5. pp. 898-917. doi: $10.1111 /$ tpj.13456

3. Sokolenko, N.I., Komarov, N.M. (2019). Adaptive features of winter wheat varieties of the world collection. Taurida herald of the agrarian sciences. no. 4 (20). pp. 111-116. DOI 10.33952/ 2542-0720-2019-4-20-111-116 (in Russian).

4. Vasyliuk, P.M. (2014). Assessment of stability and plasticity of productivity indicators and quality of new varieties of soft winter wheat in the forest-steppe of Ukraine. Plant Varieties Studying and Protection. no. 1. pp. 15-18 (in Ukrainian).

5. Yanishevskyi, L.I. (2013). Ecological stability and plasticity of oilseed flax varieties. Bulletin of Kharkiv National Agrarian University named after V.V. Dokychaiev. The series "Crop production, selection and seed production, fruit and vegetable growing". no. 1. pp. 339-343 (in Ukrainian).

6. Prysiazhniuk, O.I., Kaliuzhna, E.A., Ukrainets, V.V., Shevchenko, O.P. (2013). Stability and plasticity of pea varieties selected by the Ulado-Lyulinets experimental breeding station. Sugar Beet. no. 6. pp. 19-20. (in Ukrainian).

7. Khomenko, S.O., Kochmarskyi, V.S., Fedorenko, I.V., Fedorenko, M.V. (2018). Stability and plasticity of collection samples of bread spring wheat by productivity indices. Bulletin of Uman National University of Horticulture. no. 1. pp. 43-47. DOI: 10.31395/2310-0478-2018-1-43-47 (in Ukrainian).

8. Kalenskaya, S.M., Melnyk, A.V., Polezhay, A.G. (2013). Plasticity and stability of modern varieties and hybrids of spring rape in the Left-Bank Forest-Steppe of Ukraine. Bulletin of Sumy National Agrarian University : 
Series, Agronomy and Biology. Iss. 3 (25). pp. 238-241 (in Ukrainian).

9. Dimitrov, S. (2015). The reaction of new sunflower hybrids was studied in growing conditions in the areas of unstable and insufficient moisturing. Collection of scientific works of the National Scientific Center "Institute of Agriculture of NAAS". Iss. 3. pp. 117-124 (in Ukrainian).

10. Beliavskaia, L.H., Dyianova, A.A., Beliavskyi, Yu.V. (2018). Results of the assessment of the plasticity and stability of soybean varieties. Materials of the International Scientific Symposium "85 years of the Faculty of Agronomyachievements and prospects", dedicated to the 85th anniversary of the foundation State Agrarian University of Moldova. Chisinau, 2018, Vol. 52 (1), pp. 190-195 (in Russian).

11. Starychenko, V.M., Holyk, L.M., Tkachova, N.A., Lytus, M.V. (2014). The estimation of the adaptive abilities and stability of varieties and breeder lines in the bread wheat breeding. Plant Breeding and Seed Production. Iss. 105. pp. 77-84. https://doi.org/10.30835/2413-7510.2014.42055 (in Ukrainian).

12. Petrov, L.K. (2020). Assessment of yield, environmental stability and plasticity of winter wheat varieties in the conditions of the Nizhny Novgorod region. Rossiiskaia selskokhoziaistvennaia nauka. no. 3. pp. 6-9. DOI: $10.31857 /$ S2500262720030023 (in Russian).

13. Sukhorukov, A.F., Sukhorukov, A.A. (2019). Adaptive potential of winter wheat patrnt material in the Middle Volga region. Rossiiskaia selskokhoziaistvennaia nauka. no. 2. pp. 3-6. https://doi.org/10.31857/S25002627201923-6 (in Russian).

14. Bebiakyn, V.M., Rozanova, T.A., Zlobyna, L.N. (2013). Regression analysis of plasticity and phenotypic stability of hybrid populations of spring wheat by gluten quality. Russian Agricultural Sciences. no. 5. pp. 12-13 (in Russian).

15. Leonov, O.Yu. (2013). Grouping of common wheat samples on plasticity and stability expression of quantitative traits. Plant Genetic Resources. no. 13. pp. 28-39 (in Ukrainian).

16. Tischenko, V.N., Panchenko, P.M., Chernyshova, O.P. (2013). Identification of the sorts of breeding lines of winter wheat with respect to balanceness of quantitative characteristics using cluster analysis. Bulletin of Poltava State Agrarian Academy. no. 3. pp. 28-36 (in Russian).

17. State register of plant varieties suitable for dissemination in Ukraine in 2021. (2021). URL: https:// agro.me.gov.ua/storage/app/uploads/public/605/9dc/d94/ 6059dcd944bfb029961931.pdf (in Ukrainian).

18. Eberhart, S.A., Russell, W.A. (1966). Stability parameters for comparing varieties. Crop Sci. Vol. 6. pp. 36-40. https://doi.org/10.2135/cropsci1966.0011183X000 $600010011 x$

19. Surkova, L.Y., Klymashevskyi, E.L., Chevzhyk, A.L. et al. (1992). The reaction of winter wheat varieties to fertilizer and the inheritance of the responsiveness trait in systemic crosses. Agricultural Chemistry. no. 3. pp. 41-52 (in Russian).

20. Koliuchyi, V.T. (2011). Breeding of winter wheat for grain quality in the Forest-steppe of Ukraine. Plant Breeding and Seed Production. Iss. 100. pp. 160-171 (in Ukrainian).

21. Zhemela, H.P., Kurochka, A.O. (2012). Effect of predecessors on elements of yield structure and quality of winter wheat grain depending on varietal properties. Bulletin of Poltava State Agrarian Academy.. no. 1, pp. 33-36 (in Ukrainian). 